\title{
Effect of the Indigenous Microflora on the Development of Root and Crown Rot Caused by Pythium aphanidermatum in Cucumber Grown on Rockwool
}

\author{
Joeke Postma, Margarit J. E. I. M. Willemsen-de Klein, and Jan Dirk van Elsas
}

Research Institute for Plant Protection (IPO), P.O. Box 9060, 6700 GW Wageningen, the Netherlands. Accepted for publication 3 October 1999.

\begin{abstract}
Postma, J., Willemsen-de Klein, M. J. E. I. M., and van Elsas, J. D. 2000. Effect of the indigenous microflora on the development of root and crown rot caused by Pythium aphanidermatum in cucumber grown on rockwool. Phytopathology 90:125-133.

The capacity of the microflora in rockwool to suppress Pythium aphanidermatum, the causative agent of root and crown rot in cucumber, was assessed. Disease development of cucumber (Cucumis sativus) grown on rockwool was evaluated in an "ebb-and-flood" system with a recirculating nutrient solution after inoculation with $P$. aphanidermatum. In five independent experiments from 1995 to 1998,11 batches of used rockwool were tested. All batches without $P$. aphanidermatum problems in the preceding cucumber crop had significantly lower numbers of diseased plants in nonautoclaved than in autoclaved used rockwool; the disease incidence was reduced by 52 to $100 \%$. Suppressiveness also was present in rockwool previously used to grow other vegetable crops. Rockwool originating from a cucumber crop that was severely attacked by Pythium resulted in a high disease incidence. Previously unused (new) rockwool had higher or similar percentages of diseased plants than did nonsterilized

croflora. Population sizes of total culturable aerobic bacteria as well as of fluorescent pseudomonads did not correlate with disease suppressiveness, as numbers of bacteria and pseudomonads were similar or lower in nonautoclaved (suppressive) than in autoclaved (nonsuppressive) rockwool. Differences in the structure of the bacterial populations could be visualized by using eubacterial polymerase chain reaction (PCR) followed by denaturing gradient gel electrophoresis (DGGE). Interestingly, the nonautoclaved and the recolonized used rockwool, which were both suppressive, showed different dominating bacterial groups as compared with the autoclaved rockwool. PCR-DGGE patterns obtained at different sampling times showed that the composition of the bacterial populations changed during plant growth. Fungal populations were present in the treatments that yielded suppressive rockwool, i.e., the nonautoclaved and the recolonized rockwool, but they were absent or present in low numbers in the autoclaved rockwool, which permitted a high disease incidence. Suppressiveness of rockwool to Pythium root and crown rot is a hitherto undescribed phenomenon, and knowledge of the mechanism and microorganisms involved will stimulate the development of microbially balanced soilless growing systems.
\end{abstract} used rockwool. Disease suppression in used rockwool could also be measured in a smaller test system. In both systems, autoclaved rockwool became suppressive to Pythium after recolonization with the indigenous mi-
Additional keywords: competition, disease suppressive substrate, plate counts, recirculated nutrient solution.
The oomycetes Pythium and Phytophthora spp. are well adapted to aquatic life and flourish in substrates like rockwool that exhibit a high water retention capacity $(3,28)$. Most of the oomycetes are able to produce zoospores, which can actively swim to their hosts. Damage by Pythium spp. is particularly severe in the early stages of seedling growth to plants growing in soil or soilless systems. Adult plants may also be affected in soilless systems $(3,15)$. The resulting root loss can cause considerable damage to a cucumber (Cucumis sativus L.) crop. Of the numerous Pythium spp. that can cause root rot of greenhouse-grown cucumber, $P$. aphanidermatum (Edson) Fitzp. is the most widely reported $(6,15,20,25)$. Pythium spp. are difficult to control. In the short term, there are no prospects for breeding resistant cultivars. Fungicides (i.e., propamocarb and metalaxyl) are only effective if used as preventive applications. In some countries, these fungicides are not registered for use on vegetable crops cultivated in hydroponic systems $(25,29,32)$. In the Netherlands, where propamocarb is registered, $15 \%$ of all chemicals applied in greenhouse cucumbers are used to prevent losses due to Pythium spp. The current objective of the Dutch government is to decrease pesticide use.

Corresponding author: J. Postma; E-mail address: J.Postma@ ipo.wag-ur.nl

Publication no. P-1999-1213-01R

(c) 2000 The American Phytopathological Society
Problems with zoospore-producing fungi are likely to increase now that nutrient solutions are recirculated to prevent environmental pollution $(14,28)$. Sterilization of the nutrient solution by UV irradiation, heat, or filtration is expensive and targets only the recirculating solution. Zoospore lysis with surfactants can control the spread of zoospores via the recirculating nutrient solution, but it does not affect encysted zoospores (29). Several antagonistic microorganisms such as Pseudomonas spp., Streptomyces spp., Trichoderma spp., Bacillus spp., Enterobacter cloacae, and P. oligandrum have the potential to control $P$. aphanidermatum $(4,13,16,19,22$, $23,27,35)$. However, effects of biocontrol agents in soilless systems often were insufficient or difficult to reproduce (25; J. Postma and H. Rattink, unpublished data).

Pythium spp. are poor competitors relative to other root-colonizing organisms $(9,25)$. Thus, introduced or indigenous microorganisms are expected to be able to reduce disease caused by $P y$ thium by competing for nutrients. Insufficient biocontrol of $P$. aphanidermatum in soilless systems by introduced microorganisms can be due to a lack of survival or to insufficient colonization of the infection sites. Moreover, combinations of microorganisms sometimes are more effective at controlling or competing with Pythium $(21,32)$. Indigenous microorganisms have several advantages: (i) they are already present, (ii) they are adapted to the environment, and (iii) they form stable complex communities. The existence of a suppressive microflora toward Pythium in soil and peat is generally accepted $(33,34)$. For soilless systems, as far as we know, 
only one example of a suppressive microflora (i.e., toward Fusarium wilt) has been presented (26).

In soilless systems, the numbers of microorganisms are often low at the start of a crop. These numbers, however, increase rapidly as plants grow. For example, bacterial numbers in a nutrient solution increased from $10^{3}$ to $10^{6} \mathrm{CFU}$ per $\mathrm{ml}$ within $20 \mathrm{~h}$ due to the presence of plants (2). In the Netherlands, the common greenhouse practice is to start cucumber production each year on new rockwool or to steam the substrate in the case of previously used rockwool. During 1 year, rockwool slabs are reused for several cucumber crops without steaming before planting. This implies a potential buildup of microflora (numbers and probably diversity). However, data on the microorganisms present in soilless systems are scarce and information about their influence on Pythium spp. is absent.

The aim of the current study was to evaluate the capacity of the indigenous microflora to suppress the $P$. aphanidermatum causing root and crown rot in cucumber grown on rockwool. Several greenhouse experiments were conducted with previously unused (new) or used rockwool slabs with different histories: (i) rockwool from several cucumber growers, (ii) rockwool with and without Pythium present in the preceding crop, (iii) rockwool with different numbers of preceding crops of cucumber, and (iv) rockwool with other preceding vegetable crops. New rockwool was compared with used rockwool that was nonautoclaved, autoclaved, or recolonized after autoclaving. The dynamics and diversity of the microbial populations in the rockwool were studied using plate counts on semiselective media and a molecular technique that patterns the bacterial communities, i.e., eubacterial polymerase chain reaction (PCR) followed by denaturing gradient gel electrophoresis (DGGE).

\section{MATERIALS AND METHODS}

Fungal pathogen. In all experiments, a mixture of $P$. aphanidermatum isolates 89 and 301 was used. These isolates were obtained from hydroponically grown cucumbers and were supplied by P. Paternotte (Research Station for Floriculture and Glasshouse Vegetables, Naaldwijk, the Netherlands). Isolates were cultured in $100-\mathrm{ml}$ Erlenmeyer flasks containing $20 \mathrm{ml}$ of V8 liquid medium ( $200 \mathrm{ml}$ of $\mathrm{V} 8$ and $3 \mathrm{~g}$ of $\mathrm{CaCO}_{3}$ per liter of deionized water, autoclaved $20 \mathrm{~min}$ at $105^{\circ} \mathrm{C}$ ). Flasks were incubated for 7 days at $25^{\circ} \mathrm{C}$ in the dark without shaking. Mycelial mats were then washed four times with approximately $50 \mathrm{ml}$ of water, blended for $30 \mathrm{~s}$ at high speed in a blender (Waring, New Hartford, CT), and filtered through cheesecloth. Oospores were counted with the aid of a haemocy- tometer. Stock cultures were stored on V8 agar in liquid nitrogen. Cultures for the experiments were kept on cornmeal agar (Oxoid Ltd., Basingstoke, United Kingdom) with $100 \mathrm{mg}$ of streptomycin (Duchefa, Haarlem, the Netherlands) per liter and $10 \mathrm{mg}$ of tetracycline (Duchefa) per liter to avoid bacterial contamination.

Cultivation of plants on rockwool in the "ebb-and-flood" system. With a cork borer, 24-mm-diameter holes were made in rockwool cubes $(4 \times 4 \times 4 \mathrm{~cm})$ (Rockwool/Grodan BV, Roermond, the Netherlands), whereafter they were saturated with a cucumber nutrient solution ( $\mathrm{pH} 5.5$; electrical conductivity $2.4 \mathrm{mS} / \mathrm{cm}$ ). The nutrient solution contained $972 \mathrm{mg}$ of $\mathrm{Ca}\left(\mathrm{NO}_{3}\right)_{2} \cdot 4 \mathrm{H}_{2} \mathrm{O}, 55 \mathrm{mg}$ of $\mathrm{NH}_{4} \mathrm{NO}_{3}, 557 \mathrm{mg}$ of $\mathrm{KNO}_{3}, 20 \mathrm{mg}$ of Fe-DTPA (diethyltriaminepentaacetic acid) (Librel, $\mathrm{FeDP}_{7}$; Tuhamÿ $\mathrm{BV}$, 's Gravenzande, the Netherlands) (7\%), $170 \mathrm{mg}$ of $\mathrm{KH}_{2} \mathrm{PO}_{4}, 616 \mathrm{mg}$ of $\mathrm{MgSO}_{4} .7 \mathrm{H}_{2} \mathrm{O}$, $140 \mathrm{mg}$ of $\mathrm{NaNO}_{3}, 1.7 \mathrm{mg}$ of $\mathrm{MnSO}_{4}, 1.45 \mathrm{mg}$ of $\mathrm{ZnSO}_{4} .7 \mathrm{H}_{2} \mathrm{O}$, $3.35 \mathrm{mg}$ of $\mathrm{B}_{4} \mathrm{Na}_{2} \mathrm{O}_{7} .10 \mathrm{H}_{2} \mathrm{O}, 0.25 \mathrm{mg}$ of $\mathrm{CuSO}_{4} .5 \mathrm{H}_{2} \mathrm{O}$, and $0.12 \mathrm{mg}$ of $\mathrm{Na}_{2} \mathrm{MoO}_{4} \cdot 2 \mathrm{H}_{2} \mathrm{O}$ per liter of water, and the $\mathrm{pH}$ was adjusted with $\mathrm{H}_{3} \mathrm{PO}_{4}$. A single cucumber seed (C. sativus cv. Tyria, nontreated seed) (ENZA Zaden BV, Enkhuizen, the Netherlands) was placed in the hole of each rockwool cube and covered with vermiculite. Cucumber seeds were allowed to germinate in closed containers exposed to daylight at $25^{\circ} \mathrm{C}$ for 5 days and were then placed on rockwool slabs in the "ebb-and-flood" units. Each unit contained 12 cucumber plants in the upper container, which measured $55 \times 75 \mathrm{~cm}$. Each unit started with 30 liters of cucumber nutrient solution, which was pumped from the reservoir to the upper container for $2 \mathrm{~min}$, resulting in a maximum height of the solution of 3 to $4 \mathrm{~cm}$. It took about $20 \mathrm{~min}$ for the upper container to be emptied. Depending on the age of the plants, they were flooded three to five times a week. Greenhouse temperature was maintained at $19 / 25 \pm 1{ }^{\circ} \mathrm{C}$ (night/day). Relative humidity was $70 \%$ at the beginning of the experiment but raised to $90 \%$ when plants grew larger. Additional light was given if daylight was less than $250 \mathrm{~W} / \mathrm{m}^{2}$.

The number of plants infected by Pythium and showing symptoms typical of root and crown rot (brown stem base and wilted and dead plants) was determined twice a week. If necessary, disease development was stimulated by flooding for $20 \mathrm{~h}$ at about 20 days after sowing. Each treatment consisted of four independent units arranged in a randomized block design.

Disease development on used rockwool slabs obtained from growers. Rockwool slabs (approximately $6 \mathrm{~cm}$ high) used for the production of cucumbers were collected and cut in $15 \times 20-\mathrm{cm}$ pieces after removal of the plastic. Part of the slabs was autoclaved $\left(20 \mathrm{~min}\right.$ at $\left.121^{\circ} \mathrm{C}\right)$. Five days later, Pythium inoculum $(50 \mathrm{ml})$

TABLE 1. Characteristics of different rockwool slabs and disease incidence of cucumber plants in the "ebb-and-flood" system on these slabs after different treatments

\begin{tabular}{|c|c|c|c|c|c|c|c|}
\hline \multirow[b]{2}{*}{ Year $^{\mathrm{u}}$} & \multirow[b]{2}{*}{ Batch } & \multirow[b]{2}{*}{ Preceding crops } & \multirow[b]{2}{*}{ Remarks } & \multirow[b]{2}{*}{ Organic matter $(\%)^{\mathrm{v}}$} & \multicolumn{3}{|c|}{ Disease incidence $(\%)^{\mathrm{w}}$} \\
\hline & & & & & $\mathrm{au}+\mathrm{P}^{\mathrm{x}}$ & $n t+P^{x}$ & $\mathrm{nt}-\mathrm{P}^{\mathrm{x}}$ \\
\hline \multirow[t]{3}{*}{1995} & A & 1 Cucumber crop & No Pythium & N.T.y & 54 & 8 & 2 \\
\hline & B & 1 Cucumber crop & No Pythium & N.T. & 25 & 2 & 0 \\
\hline & Mean & & & & $40 \mathrm{a}^{\mathrm{z}}$ & $5 \mathrm{~b}$ & $1 \mathrm{~b}$ \\
\hline \multirow[t]{4}{*}{1996} & $\mathrm{C}$ & 1 Cucumber crop & No Pythium & $6.3 \pm 0.7$ & 25 & 6 & N.T. \\
\hline & $\mathrm{D}$ & 3 Cucumber crops & No Pythium & $10.7 \pm 8.2$ & 42 & 0 & N.T. \\
\hline & $\mathrm{E}$ & 5 Cucumber crops & P. aphanidermatum was inoculated to each crop & $14.7 \pm 5.6$ & 53 & 25 & N.T. \\
\hline & Mean & & & & $40 \mathrm{a}$ & $10 \mathrm{~b}$ & N.T. \\
\hline \multirow[t]{3}{*}{1997} & $\mathrm{~F}$ & 1 Cucumber crop & No Pythium & $5.3 \pm 0.9$ & $75 \mathrm{a}$ & $6 \mathrm{~b}$ & $0 \mathrm{~b}$ \\
\hline & $\mathrm{G}$ & 1 Cucumber crop & Serious Pythium problem & $5.2 \pm 0.4$ & $56 \mathrm{a}$ & $54 \mathrm{a}$ & $50 \mathrm{a}$ \\
\hline & New & No crop & & & N.T. & $54 \mathrm{a}$ & N.T. \\
\hline \multirow[t]{4}{*}{1998} & $\mathrm{H}$ & 2 Cucumber crops & No Pythium & $10.4 \pm 4.0$ & 60 & 29 & N.T. \\
\hline & I & 1 Tomato crop & No Pythium & $8.0 \pm 1.0$ & 71 & 10 & N.T. \\
\hline & $\mathrm{J}$ & 2 Pepper crops & No Pythium & $10.3 \pm 2.8$ & 73 & 6 & N.T. \\
\hline & Mean & & & & $68 \mathrm{a}$ & $15 b$ & N.T. \\
\hline
\end{tabular}

\footnotetext{
u Year in which the experiment was carried out.

${ }^{v}$ Root debris; mean value \pm standard deviation, expressed as percentage of dry weight and determined by heating air-dried samples for $6 \mathrm{~h}$ at $600^{\circ} \mathrm{C}$.

${ }^{\mathrm{w}}$ Disease incidence is the mean percentage of plants with a brown stem base, wilted, or dead.

${ }^{x}$ Rockwool slabs were autoclaved (au) or not treated (nt) followed by inoculating the surface of the rockwool with $P$. aphanidermatum (+P) or with water (-P).

y N.T. $=$ not tested.

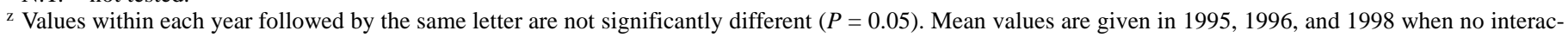
tions occurred between batch and treatment $(P<0.05)$.
} 
was added with a dispenser onto the surface of the used rockwool slabs. The 6-day-old seedlings in $4 \times 4 \times 4$-cm rockwool cubes were placed on the rockwool slabs 1 day after the pathogen was added. Experiments were conducted in the "ebb-and-flood" units as described above with four $15 \times 20$-cm pieces of the rockwool slabs, each with three seedlings. The organic matter content (dead root material) in the rockwool slabs was determined by heating air-dried samples $6 \mathrm{~h}$ at $600^{\circ} \mathrm{C}$.

In the summer of 1995, rockwool slabs were collected from two growers (Table 1). In both cases, cucumbers had been grown on the rockwool from January to June 1995 without any symptoms caused by Pythium. The inoculum concentration that was added was equivalent to $5 \times 10^{6}$ oospores per "ebb-and-flood" unit. In the summer of 1996, rockwool slabs were collected from three growers with one, three, or five preceding cucumber crops (Table 1). Batches C and D had been free of symptoms caused by Pythium, whereas batch $\mathrm{E}$ had been inoculated with $P$. aphanidermatum during each of the five preceding crops. The inoculum concentration was equivalent to $2.5 \times 10^{6}$ oospores per "ebb-and-flood" unit. In the summer of 1997, an experiment was performed to compare new with used rockwool slabs with or without Pythium problems in the preceding cucumber crop (Table 1). The inoculum concentration was $5 \times 10^{6}$ oospores per "ebb-and-flood" unit. In the winter of 1998 , rockwool slabs that had been previously used for cucumber, tomato, or pepper cultivation were collected. The inoculum concentration was $5.6 \times 10^{6}$ oospores per "ebb-and-flood" unit.

Disease suppression in different rockwool treatments in the "ebb-and-flood" system. New rockwool slabs and rockwool slabs that had been used for one preceding cucumber crop were cut into $15 \times 20$-cm pieces. Part of the used rockwool was autoclaved. Thereafter, part of the autoclaved rockwool was allowed to be recolonized via contact with saturated nonautoclaved slabs for 1.5 days. $P$. aphanidermatum $\left(6.6 \times 10^{6}\right.$ oospores per unit) was added with a dispenser to the surface of all slabs 1 day after autoclaving. The next day, 7-day-old cucumber seedlings (cv. Tyria) in $4 \times 4 \times 4$-cm rockwool cubes were placed on the slabs. Each treatment consisted of four independent units arranged in a randomized block design. Symptom development was followed for up to 35 days after sowing.

Disease suppression after elimination and addition of microorganisms in a small greenhouse test. Rockwool slabs from growers collected in the summer of 1996 (batches D and E) were cut into blocks of approximately $7 \times 7 \mathrm{~cm}$. Part of the blocks was autoclaved. Some of the autoclaved blocks were placed in contact with saturated nonautoclaved blocks for 1 day to allowed recolonization with the indigenous microflora. Streptomycin, benomyl (Benlate, 50\% a.i.; Dupont de Nemours, Dordrecht, the Netherlands), or both were added to nonautoclaved blocks by soaking the blocks 1 day in a nutrient solution containing the antibiotic, fungicide (not effective against $P$. aphanidermatum), or both. Final concentrations of $100 \mathrm{mg}$ of streptomycin per liter and $10 \mathrm{mg}$ of benomyl per liter were established. $P$. aphanidermatum $\left(5\right.$ to $8 \times 10^{5}$ oospores per plant) was added 1 day after autoclaving. One day later, 7-day-old cucumber plants (cv. Kaliber, nontreated seed; Rijk Zwaan, De Lier, the Netherlands) on $4 \times 4 \times 4$-cm rockwool cubes were placed on the blocks that were placed individually on trays. Each treatment consisted of four replicates with four plants each. Treatments were arranged in a randomized complete block design. Abiotic growth conditions were similar to that described for the "ebb-and-flood" system. Nutrient solution was added three times a week onto the tray. Symptom development was scored 19 days after sowing.

Characterization of the microflora. In two experiments in the "ebb-and-flood" system, population dynamics of total bacteria, pseudomonads, and fungi were assessed in autoclaved and nonautoclaved rockwool from different growers. The microorganisms were enumerated with plate counts 5,12 , and 19 days after part of the rockwool was autoclaved. In addition, the microbial populations in the unused cucumber nutrient solution, in new dry rock- wool, and in used moist rockwool immediately after autoclaving were analyzed. In the small greenhouse test, bacterial and fungal populations in rockwool were assessed with plate counts prior to placement of plants on the blocks. In the experiment in the "ebband-flood" system with four different rockwool treatments, population dynamics of bacteria, pseudomonads, fungi, and Trichoderma spp. in rockwool were analyzed with plate counts, as well as with PCR-DGGE, 7, 14, 21, and 35 days after sowing.

Plate counts. Microbial populations in rockwool were assessed in three replicates per treatment. Two vertical cores $(2.5 \mathrm{~cm}$ in diameter) were cut out of the rockwool from which $30 \mathrm{~g}$ of moist rockwool was shaken for $30 \mathrm{~min}$ at $400 \mathrm{rpm}$ on a rotary shaker (Elbanton, Kerkdriel, the Netherlands) in a 250-ml Erlenmeyer flask containing $90 \mathrm{ml}$ of $0.1 \%$ sodium pyrophosphate and $10 \mathrm{~g}$ of gravel ( 2 to $4 \mathrm{~mm}$ in diameter). Appropriate dilutions were plated in triplicate on different media using a spiral plater (WASP; Don Whitley Scientific Limited, Shipley, United Kingdom). Total aerobic heterotrophic bacteria was enumerated on $1 / 10$-strength tryptic soy agar (TSA; $4 \mathrm{~g}$ of TSA [Oxoid Ltd.], $13.5 \mathrm{~g}$ of agar, and $100 \mathrm{mg}$ of cycloheximide per liter of deionized water). Total fungal propagules was enumerated on $1 / 4$-strength potato dextrose agar (PDA; $10 \mathrm{~g}$ of PDA [Oxoid Ltd.], $16 \mathrm{~g}$ of agar, $100 \mathrm{mg}$ of streptomycin, $10 \mathrm{mg}$ of tetracycline, and $2 \mathrm{ml}$ of Triton X-100 per liter of deionized water). Triton X-100 was added to PDA to limit mycelial growth. Trichoderma spp. could be distinguished on PDA by its color and growth characteristics. Plates were incubated for 7 days at $20^{\circ} \mathrm{C}$. Fluorescent pseudomonads were enumerated on King's B agar (20 g of proteose peptone No. 3 [Difco Laboratories, Detroit], $1.5 \mathrm{~g}$ of $\mathrm{K}_{2} \mathrm{HPO}_{4}$, $1.5 \mathrm{~g}$ of $\mathrm{MgSO}_{4} .7 \mathrm{H}_{2} \mathrm{O}, 15 \mathrm{ml}$ of glycerol [99\%], $13.5 \mathrm{~g}$ of agar, and $100 \mathrm{mg}$ of cycloheximide per liter of deionized water) (under UV light) after 2 days of incubation at $25^{\circ} \mathrm{C}$. All data were calculated to correspond with CFU per gram of moist rockwool.

DNA extraction for PCR-DGGE analysis. The diversity and structure of the bacterial communities were analyzed with DGGE of PCR-amplified bacterial $16 \mathrm{~S}$ rDNA extracted from the rockwool. Three samples per treatment were taken. Two vertical cores $(2.5 \mathrm{~cm}$ in diameter) were cut out of the rockwool of each replicate, from which $2 \mathrm{~g}$ of rockwool was sampled. In a bead beater (Braun cell homogenizer; Braun, Melsungen, Germany), the 2-g rockwool sample was homogenized three times for $30 \mathrm{~s}(10 \mathrm{~s}$ rest in between) in $3 \mathrm{ml}$ of $0.12 \mathrm{M}$ sodium phosphate buffer ( $\mathrm{pH} \mathrm{8.0)}$ supplemented with $3 \mathrm{~g}$ of glass beads ( 0.10 to $0.11 \mu \mathrm{m}$ in diameter). The homogenate was then mixed with $180 \mu \mathrm{l}$ of $20 \%$ (wt/wt) sodium dodecyl sulfate and incubated on ice for $10 \mathrm{~min}$. After mixing the suspension with $3 \mathrm{ml}$ of phenol ( $\mathrm{pH} \mathrm{8.0)}$ and centrifuging at $8,000 \times g$ for $10 \mathrm{~min}$, the upper water layer containing the DNA was mixed with $3 \mathrm{ml}$ of chloroform/isoamylalcohol (24:1). The resulting emulsion was centrifuged at $8,000 \times g$ for $10 \mathrm{~min}$ and the upper water layer mixed gently with 0.1 volume of $5 \mathrm{M} \mathrm{NaCl}$ and 0.6 volume of isopropanol to precipitate the DNA. The suspension was centrifuged at $8,000 \times g$ for $10 \mathrm{~min}$, the supernatant removed, and the pellet washed with $2.5 \mathrm{ml}$ of $70 \%$ ethanol. After centrifuging for $10 \mathrm{~min}$ at $8,000 \times g$ and removing the ethanol, the pellet was air-dried and dissolved in $100 \mu \mathrm{l}$ of demineralized water (crude extract). From this crude extract, $50 \mu \mathrm{l}$ was purified with a Wizard DNA Clean-up Kit (Promega Benelux, Leiden, the Netherlands) according to the manual provided by the manufacturer, and the DNA was used as a template for PCR.

PCR amplification of bacterial DNA. A variable region, between positions 968 and 1,401 on the eubacterial bacterial 16S rDNA (Escherichia coli numbering system), was enzymatically multiplied in a touch-down PCR with two primers to conserved regions (10). Primer 1 (F968GC1; Pharmacia Biotech, Roosendaal, the Netherlands) had the following sequence: 5'-CGCCCGGGGCGCGCCCCGGGCGGGGCGGGGGCACGGGGGGAACGCGAAGAACCTTAC$3^{\prime}$. The first 40 bases represent a GC-rich sequence (GC clamp) that does not denature on the gradient gel and keeps the two single strands of DNA together after melting of the amplicons. More 
details are described by Muyzer et al. $(17,18)$. The sequence of primer 2 (L1401; Pharmacia Biotech) was 5'-GCGTGTGTACAAGACCC-3'. In a Peltier Thermal Cycler-200 (Biozym, Landgraaf, the Netherlands), PCR was performed in a $50 \mu \mathrm{l}$ volume containing 10 to $20 \mathrm{ng}$ of purified rockwool DNA, $1 \times$ Stoffelbuffer (Perkin Elmer, Nieuwerkerk a/d IJssel, the Netherlands), $200 \mu \mathrm{M}$ of each dNTP (Boehringer, Almere, the Netherlands), $3.75 \mathrm{mM}$ $\mathrm{MgCl}_{2}, 0.2 \mu \mathrm{M}$ primer $1,0.2 \mu \mathrm{M}$ primer $2,1 \%$ formamide (Merck, Amsterdam, the Netherlands), $0.25 \mu \mathrm{g}$ of T4 gene 32 protein (Boehringer), and $5 \mathrm{U}$ of AmpliTaq DNA Polymerase (Stoffelfragment; Perkin Elmer). The samples were incubated for $3 \mathrm{~min}$ at $95^{\circ} \mathrm{C}$ to denature the template DNA, followed by two PCR cycles of 1 min at $94^{\circ} \mathrm{C}, 1 \mathrm{~min}$ at $65^{\circ} \mathrm{C}$, and $2 \mathrm{~min}$ at $72^{\circ} \mathrm{C}$. The next cycles were the same, except for the annealing temperature, which was lowered 2 degrees every second cycle until $55^{\circ} \mathrm{C}$, at which temperature another 30 cycles were performed. Primer extension was done for $10 \mathrm{~min}$ at $72^{\circ} \mathrm{C}$, after which the amplification products were analyzed by electrophoresis in $1.2 \%$ agarose gel at $150 \mathrm{~V}$.

DGGE. Two acrylamide solutions with denaturant concentrations of 45 and $65 \%$ were obtained by mixing a $0 \%$ denaturant acrylamide solution and an $80 \%$ denaturant acrylamide solution in the proportions $11: 14$ and 4.7:20.3, respectively. The $0 \%$ denaturant solution consisted of $1 \times$ Tris-acetate-EDTA (TAE; $40 \mathrm{mM}$ Tris base [Boehringer]), $20 \mathrm{mM} \mathrm{NaAc}, 1 \mathrm{mM}$ EDTA (pH 7.8), and 6\% acrylamide 4K Mix (AppliChem, Darmstadt, Germany). The 80\% denaturant solution consisted of the same substances and 5.6 M urea and $32 \%$ (vol/vol) deionized formamide (Merck). DGGE gels with a 45 to $65 \%$ denaturant gradient were performed with a gradient mixer in a DGGE setup (Ingeny, Goes, the Netherlands). Polymerization of the gels was initiated by the addition of $150 \mu \mathrm{l}$ of $10 \%$ (wt/vol) APS (ammonium peroxodisulfate; Bio-Rad Laboratories, Veenendaal, the Netherlands) and $12 \mu \mathrm{l}$ of TEMED (tetramethylethylenediamine; Sigma, Zwijndrecht, the Netherlands) to $25 \mathrm{ml}$ of each acrylamide solution.

The PCR products were applied onto a top layer of $5 \mathrm{ml}$ of $0 \%$ denaturant polyacrylamide gel. The electrophoresis was performed in $0.5 \times \mathrm{TAE}$ at $100 \mathrm{~V}$ at $60^{\circ} \mathrm{C}$. After $16 \mathrm{~h}$, the DNA in the gel was stained by incubating it with $0.5 \times \mathrm{TAE}+0.025 \%$ SYBR Green I (Molecular Probes, Leiden, the Netherlands) for $60 \mathrm{~min}$ and analyzed under UV light.

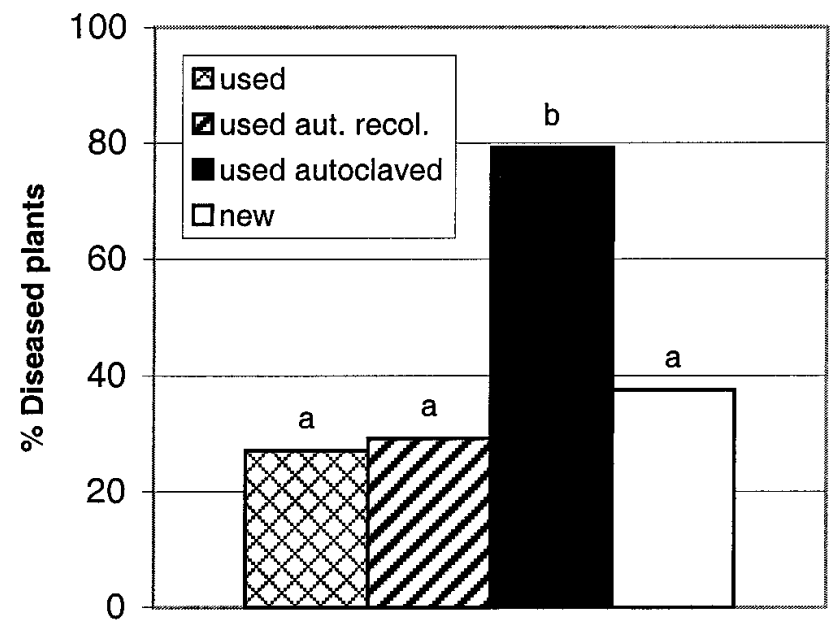

Treatment

Fig. 1. Disease incidence $(\%)$ of cucumber plants growing on rockwool in the "ebb-and-flood" system after inoculation with Pythium aphanidermatum $\left(6.6 \times 10^{6}\right.$ oospores per "ebb-and-flood" unit with 12 plants $)$. Plants were grown on used nontreated, used autoclaved (aut.) and recolonized (recol.), used autoclaved, or new rockwool slabs. Disease incidence is the mean percentage of plants either with a brown stem base, wilted, or dead 35 days after sowing. Bars with the same letter are not significantly different according to the least significant difference test $(P<0.05)$.
The DGGE patterns were analyzed by clustering the different lanes by Pearson's product-moment correlation coefficient with Molecular Analyst Fingerprinting (version 1.12; Bio-Rad Laboratories, Hercules, CA), using the unweighted pair-group method using arithmetic averages clustering algorithm and no optimization (24). In addition, the different gels of the four sampling dates were combined linearly (superimposed) using the gel markers. Data were quantified according to the heights of the peaks (three-points position tolerance), and the number of bands per lane and each position per treatment was counted.

Statistical analyses. Analyses of variance (ANOVA) were carried out with the statistical program Genstat 5 release 3.1 (Rothamsted Experimental Station, Harpenden, United Kingdom). After ANOVA, least significant differences were calculated at a significance level of $P=0.05$. If necessary, disease percentages were analyzed after square-root transformation to stabilize variance. The microbial populations were analyzed following a split-plot design with treatments on main plots and with days after sowing on subplots. Numbers of microorganisms were analyzed after logarithmic $\left(\log _{10}[\mathrm{CFU}+1]\right)$ transformation.

\section{RESULTS}

Disease development on used rockwool slabs obtained from growers. Suppression of Pythium-induced root and crown rot by the indigenous microflora in used rockwool was detected in all slabs in which Pythium had not been present in the preceding crop (batches A, B, C, D, F, H, I, and J) (Table 1). After the addition of $P$. aphanidermatum, significantly higher disease percentages were recorded in the autoclaved rockwool than in nonautoclaved rockwool slabs. In particular, slabs B and D, which were collected from the same grower, showed remarkably low disease percentages ( 2 and $0 \%$, respectively). Also, slabs that had been used to grow other crops, i.e., tomato (batch I) and pepper (batch J), were highly suppressive. New rockwool also had significantly more diseased plants than did nonautoclaved used rockwool without Pythium symptoms in the preceding crop (batch F) and an equal number of diseased plants to that on autoclaved rockwool. Plants on rockwool slabs free of Pythium in the preceding crop remained free or nearly free of root and crown rot when $P$. aphanidermatum had not been added.

Rockwool slabs obtained from growers with symptoms of $P y$ thium in their crops showed different results compared with the slabs that had been free of Pythium symptoms in the preceding crop. Plants growing on rockwool in which Pythium was detected in one preceding cucumber crop (batch G) were seriously attacked by Pythium (54\%) (Table 1). Nonautoclaved batch E, to which Pythium had been added in all preceding cucumber crops, had a lower percentage of diseased plants $(25 \%)$ than did autoclaved rockwool.

TABLE 2. Disease incidence (\%) of 19-day-old cucumber plants after different treatments $^{\mathrm{W}}$

\begin{tabular}{lccc}
\hline & \multicolumn{3}{c}{$\%$ Diseased plants } \\
\cline { 2 - 4 } Treatment & Exp. 1 $^{\mathrm{x}}$ & Exp. 2 & Exp. 3 \\
\hline Nontreated & 6 & 0 & 0 \\
Streptomycin & 0 & 0 & 0 \\
Benomyl & 0 & 13 & 6 \\
Streptomycin + benomyl & 0 & 19 & 0 \\
Autoclaved & 56 & 69 & 38 \\
Autoclaved recolonized & 6 & N.T. & N.T. \\
LSD $(P=0.05)$ & 21 & 37 & 22
\end{tabular}

${ }^{w}$ Treatment include plants on nontreated used rockwool; on used rockwool blocks treated with streptomycin (100 mg/liter), benomyl (10 mg/liter), the combination of both; and on used rockwool that was autoclaved or recolonized after autoclaving.

$\mathrm{x}$ Three independent greenhouse tests with rockwool blocks individually placed on trays. Each treatment consisted of four replicates with each four plants.

y N.T. = not tested.

${ }^{\mathrm{z}} \mathrm{LSD}=$ least significant difference. 
Disease suppression in different rockwool treatments in the "ebb-and-flood" system. The disease incidence was significantly higher in autoclaved than in nonautoclaved used rockwool (Fig. 1). The autoclaved rockwool regained its suppressiveness due to recolonization after intimate contact with nonautoclaved rockwool. Plants growing in new rockwool showed a similar disease incidence to those growing in nonautoclaved rockwool (Fig. 1). This was different from the result in 1997, in which new rockwool seemed as conducive to Pythium as did autoclaved rockwool (Table 1).

Disease suppression after elimination and addition of microorganisms in a small greenhouse test. The three experiments showed similar results. Plants grown on used rockwool had no or very few symptoms after inoculation with Pythium (Table 2). The presence of streptomycin and benomyl had no significant effect on disease development. High numbers of diseased plants occurred only after autoclaving the rockwool. Autoclaved rockwool became suppressive again after contact with saturated nonautoclaved rockwool (Table 2).

Microbial populations in different rockwool treatments. In the different experiments in the "ebb-and-flood" system, bacterial and fungal dynamics in autoclaved and nonautoclaved used rockwool showed similar results for all rockwool batches tested. Population sizes of total bacteria and of fluorescent pseudomonads were always similar or greater in autoclaved than in nonautoclaved used rockwool slabs. Autoclaved rockwool initially contained low numbers of fungi. These numbers increased during the experiment, but they did not reach the population level found in nonautoclaved rockwool within 19 or 21 days. The results of the experiment with used, used autoclaved, recolonized used autoclaved, and new rockwool, which had been sampled up to 35 days after sowing, are presented (Fig. 2) and will be discussed in more detail.

The numbers of total culturable aerobic heterotrophic bacteria were similar in all treatments with used rockwool and did not vary greatly over time (Fig. 2). In new rockwool, for up to 14 days after sowing, population sizes of heterotrophic bacteria were smaller than those in used rockwool. At the initial stages of the experiment, populations of fluorescent pseudomonads were smaller in nonautoclaved rockwool than in the other treatments. At 21 and 35 days after sowing, numbers of fluorescent pseudomonads were similar in all treatments, with the exception of new rockwool at day 35, which we cannot explain. Population sizes of fungi were greatest in nonautoclaved, intermediate in recolonized, and least in autoclaved and new rockwool. Numbers of fungi in new and autoclaved rockwool increased up to the level found in nonautoclaved rockwool only after 35 days. Population sizes of Trichoderma spp. were greatest in nonautoclaved, intermediate in recolonized, and least in autoclaved and new rockwool.

Bacterial and fungal populations in the rockwool treatments of the small test system were in accordance with the previous results.
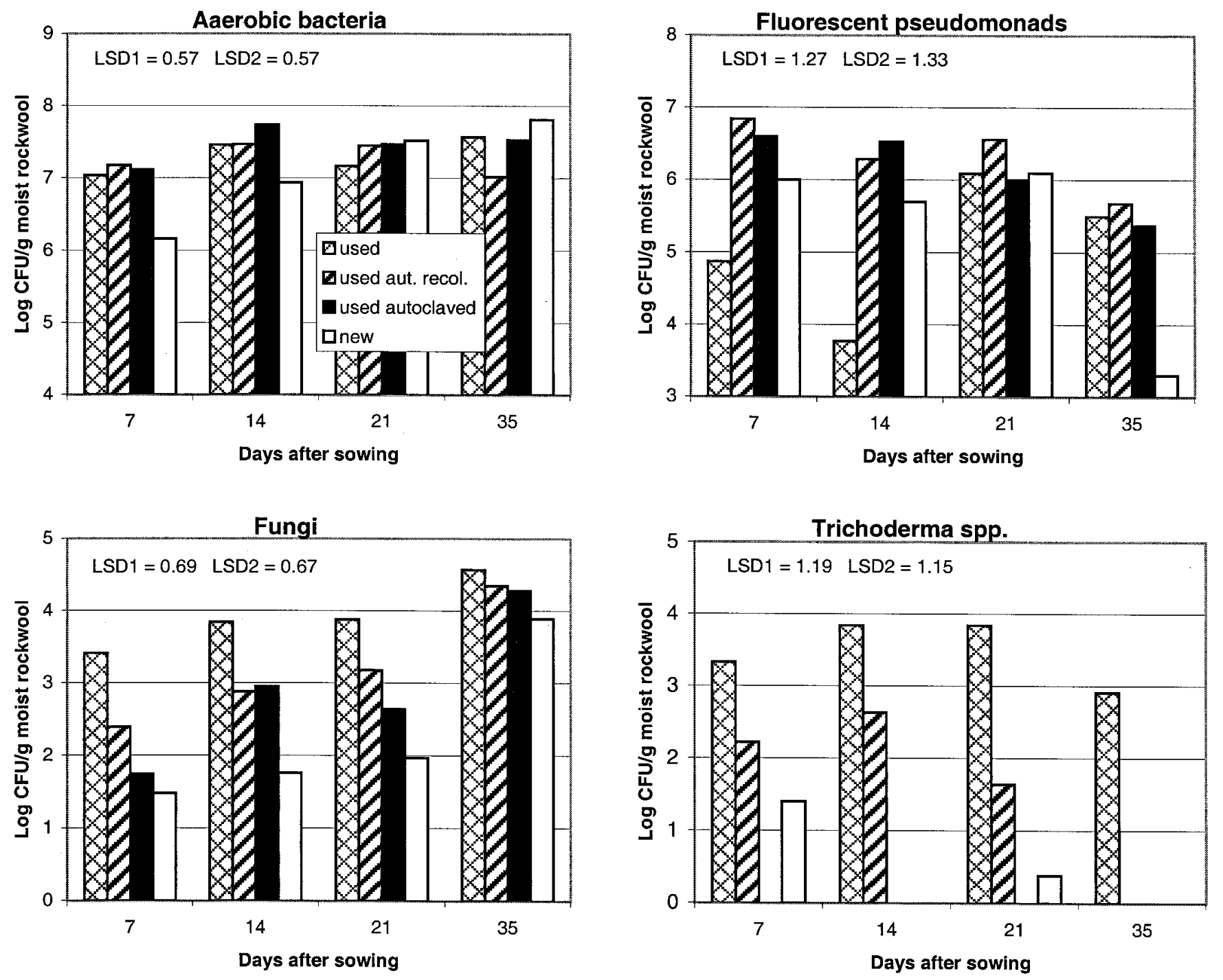

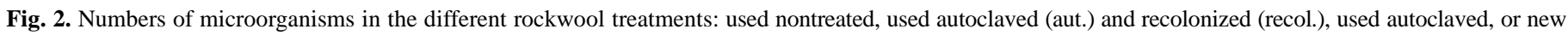

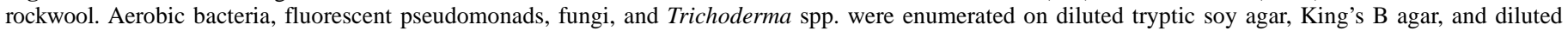
potato dextrose agar with Triton, respectively. LSD1 and LSD2 are the least significant differences between and within treatments, respectively $(P=0.05)$. 
Numbers of heterotrophic bacteria in the rockwool were similar in all treatments (Table 3). Fungal propagules were not detectable 2 days after the rockwool was autoclaved. In the other treatments, populations of fungi were around $5.8 \mathrm{log} \mathrm{CFU} / \mathrm{g}$ of rockwool. These were not significantly different from each other.

TABLE 3. Number of bacteria and fungi after different treatments ${ }^{\mathrm{w}}$

\begin{tabular}{lcc}
\hline & \multicolumn{2}{c}{ Log CFU/g of moist rockwool ${ }^{\mathrm{x}}$} \\
\cline { 2 - 3 } Treatment & Bacteria $^{\mathrm{y}}$ & Fungi $^{\mathrm{y}}$ \\
\hline Nontreated & 7.28 & 5.88 \\
Streptomycin & 7.23 & 5.83 \\
Benomyl & 7.04 & 5.43 \\
Streptomycin + benomyl & 7.12 & 5.85 \\
Autoclaved & 7.16 & 0 \\
Autoclaved recolonized & 7.26 & 5.71 \\
LSD $^{\mathrm{z}}(P=0.05)$ & 0.33 & 0.53 \\
\hline
\end{tabular}

${ }^{\text {w }}$ Treatments include plants on nontreated used rockwool; on used rockwool treated with streptomycin (100 mg/liter), benomyl (10 mg/liter), the combination of both; and on used rockwool autoclaved or recolonized after autoclaving.

${ }^{x}$ The rockwool of the first greenhouse test was sampled 2 days after it was treated.

${ }^{y}$ Bacteria are enumerated on diluted tryptic soy agar, fungi are enumerated on diluted potato dextrose agar with Triton.

${ }^{\mathrm{z}} \mathrm{LSD}=$ least significant difference.

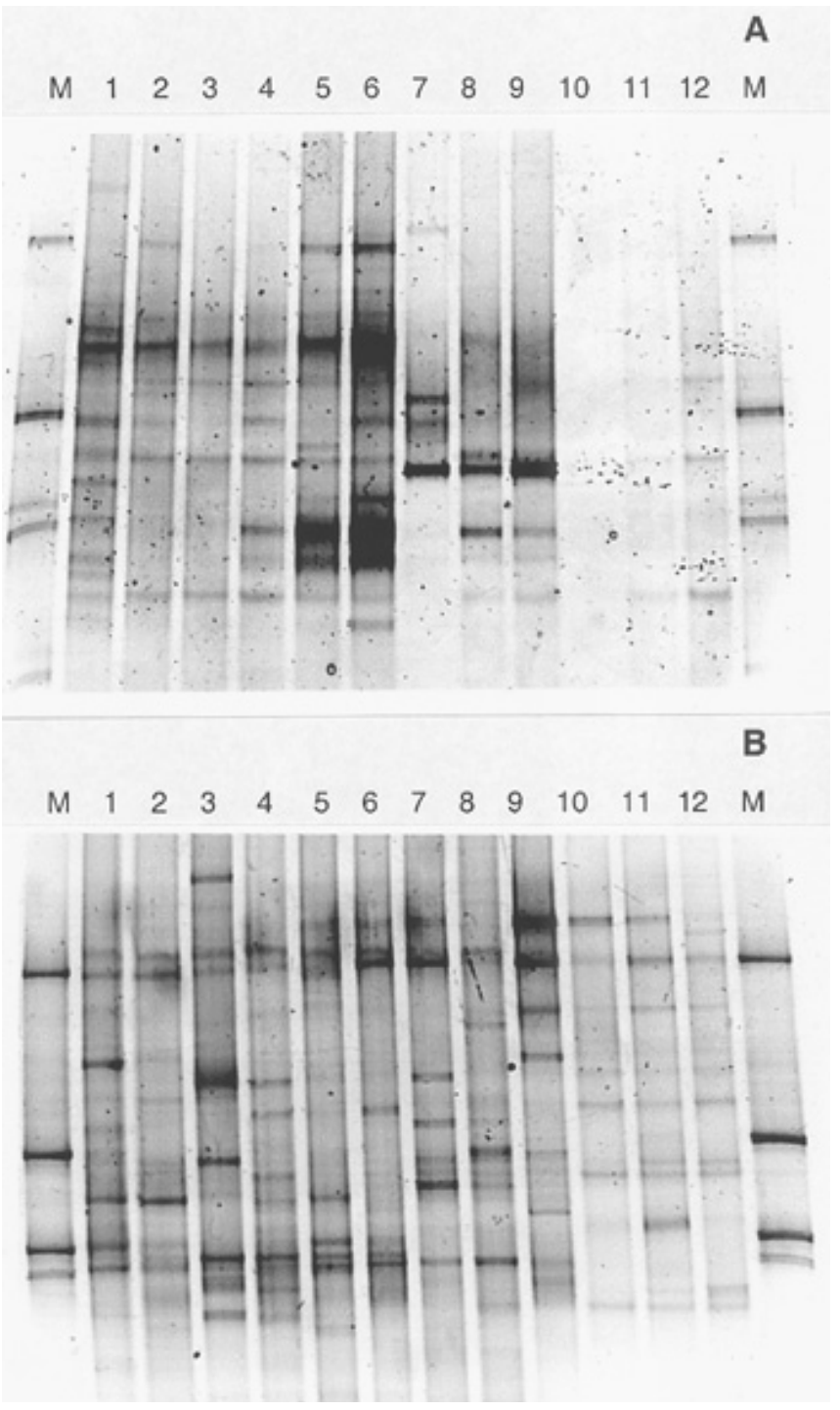

Fig. 3. Denaturing gradient gel electrophoresis patterns of the bacterial populations in different rockwool treatments. $\mathbf{A}=7$ days after sowing, and $\mathbf{B}=21$ days after sowing. Lane M, bacterial marker; lanes 1 to 3 , used nontreated rockwool; lanes 4 to 6 , recolonized used autoclaved rockwool; lanes 7 to 9 , autoclaved used rockwool; and lanes 10 to 12 , new rockwool.
New, dry rockwool contained $1.4 \times 10^{4}$ bacteria, 12 fungal propagules, and no Trichoderma spp. per g of rockwool (data not shown). Autoclaved rockwool contained less than 12 bacterial and fungal CFU per g (detection limit of the method). Before use, the cucumber nutrient solution contained $10^{5} \mathrm{CFU}$ of bacteria per $\mathrm{ml}$, whereas no fungi were detected.

DNA extraction and PCR. In all cases, DNA of high molecular weight (10 to 40 kilobases) was obtained. Yields varied between 0.2 and $10 \mu \mathrm{g}$ per $\mathrm{g}$ of rockwool, except for the initial stages of the experiment, in which the amount of DNA was sometimes too low to make a reliable estimation. This DNA, following the standard purification procedure, was sufficiently pure for efficient amplification by eubacterial PCR. Thus, PCR products of the expected size (about 450 base pairs) were obtained for all rockwool samples analyzed.

Molecular (PCR-DGGE) analysis of bacterial diversity in different rockwool treatments. The similarity of the eubacterial PCRDGGE patterns between the replicates of treatments is clearly visible in Figure 3A: (i) new rockwool had only a few weak bands, and (ii) autoclaved used rockwool had a limited number of profound bands in the middle of the pattern, whereas (iii) the replicates of the two remaining treatments had a higher number of bands and many of them occurred on the same position in the pattern. The replicates of these treatments showed 61,86 , and $76 \%$ similarity, respectively, whereas similarity between the treatments was only $48 \%$ (Fig. 4A). Thus, the variation between the treatments was larger than the variation between replicates of treatments. At a later stage of the experiment (Fig. 3B), all samples had a higher similarity (83\%) (Fig. 4B) than those in the initial stage of the experiment. Nevertheless, similarities between the replicates of some treatments were even higher $(93 \%$ for new and $92 \%$ for auto-
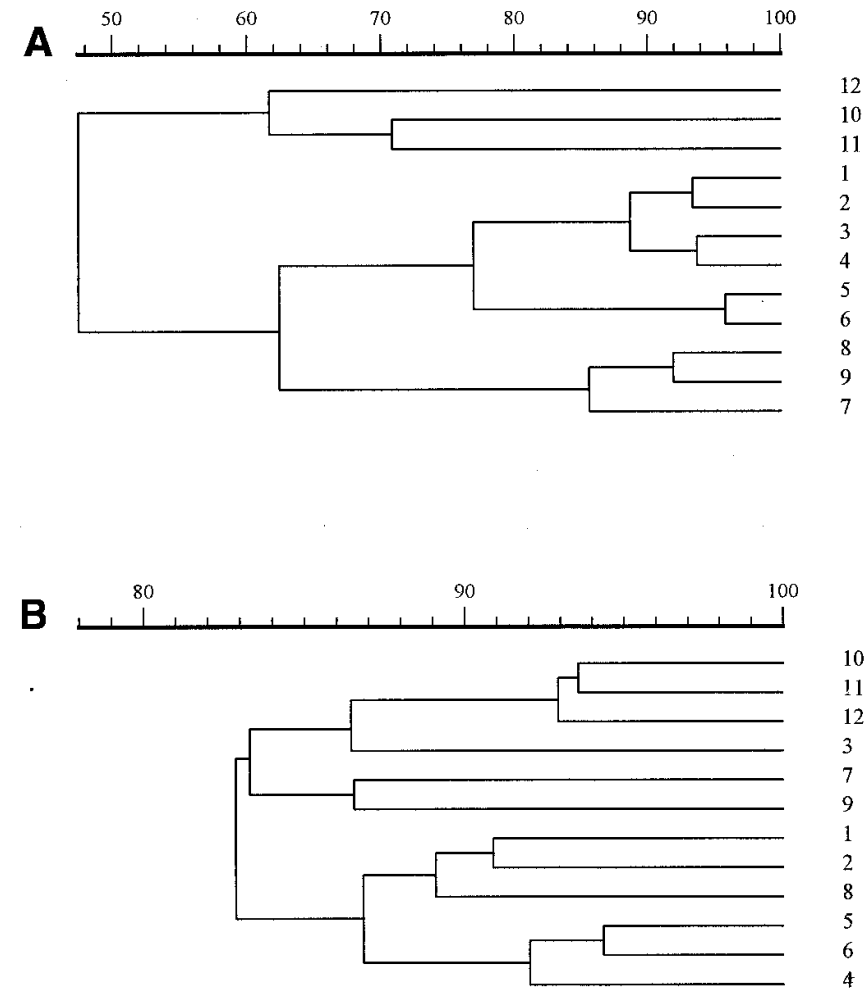

Fig. 4. Dendrogram representing genetic similarity of polymerase chain reaction-denaturing gradient gel electrophoresis-obtained patterns of the bacterial population in different rockwool treatments. $\mathbf{A}=7$ days after sowing, and $\mathbf{B}=$ 21 days after sowing. 1 to 3 , Used nontreated rockwool; 4 to 6 , recolonized used autoclaved rockwool; 7 to 9, autoclaved used rockwool; and 10 to 12, new rockwool. The scale corresponds with \% similarity as analyzed with Molecular Analyst Fingerprinting (version 1.12; Bio-Rad Laboratories, Hercules, CA) using the unweighted pair-group method using arithmetic averages clustering algorithm and no optimization. 
TABLE 4. Total number of bands in the bacterial PCR-DGGE patterns present in three replicates of each treatment at different positions in the gels

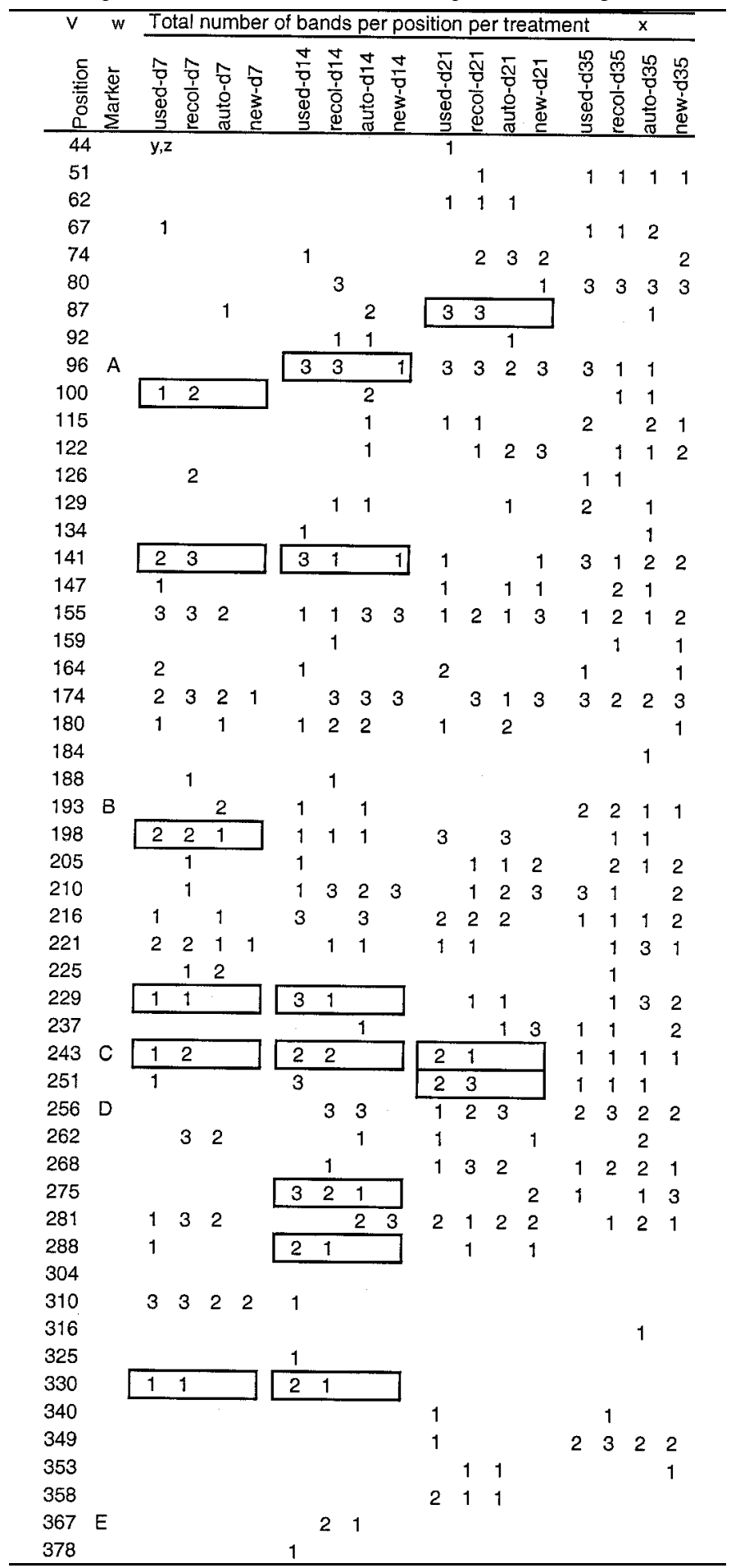

${ }^{v}$ Position (in arbitrary length units) in the linearly combined gels according to the computer program Molecular Analyst Fingerprinting (version 1.12; Bio-Rad, Hercules, CA).

${ }^{\mathrm{w}}$ Marker composed of five bacterial strains. A = Enterobacter cloaceae BE1, $\mathrm{B}=$ Listeria innocua ALM105, C = Rhizobium leguminosarum biovar trifolii, $\mathrm{D}=$ Arthrobacter $\mathrm{sp}$., and $\mathrm{E}=$ Burkholderia cepacia $\mathrm{P} 2$.

${ }^{x}$ Four rockwool treatments were sampled 7, 14, 21, and 35 days after sowing. Used $=$ used rockwool, recol $=$ autoclaved and recolonized used rockwool, auto $=$ autoclaved used rockwool, and new $=$ new rockwool. Each treatment has three replicates.

${ }^{y}$ No value indicates 0 bands in three replicates. 1,2, or 3 are the number of bands in three replicates.

${ }^{\mathrm{z}}$ Bands that occur more frequently in used and autoclaved recolonized used rockwool than in autoclaved used and new rockwool are placed in a framework. claved recolonized used rockwool). Although the eubacterial PCRDGGE patterns of the replicates are not identical, the larger variation between treatments than between replicates of treatments allows comparison of treatments with PCR-DGGE patterns.

Especially in the initial stages of the experiment, PCR-DGGE patterns showed that the structure of the bacterial communities was different between the rockwool treatments (Fig. 3A). Visual observations were supplemented with a data analysis that used as a criterion the number of bands per position per treatment for the four sampling dates (Table 4). Interestingly, some bands only occurred in the disease-suppressive treatments, i.e., nonautoclaved and autoclaved recolonized used rockwool. Seven days after sowing, bands on positions 100, 141, 198, 229, 243, and 330 were only, or primarily, present in both disease-suppressive treatments (Table 4). Fourteen and twenty-one days after sowing, seven and three bands, respectively, dominated in the disease-suppressive treatments. On day 35, such dominating bands were no longer visible. Another conclusion that can be made from Figure 3 and Table 4 is that the structure of the bacterial communities changed during the experiment.

The mean number of bands per treatment also differed in the initial stage of the experiment. PCR-DGGE patterns in the new rockwool had lower numbers of bands than those of the used rockwool treatments up to day 14 (Table 5). Twenty-one and thirtyfive days after sowing, differences in the numbers of bands were no longer observed (Table 5).

As already mentioned, the PCR-DGGE patterns in new rockwool 7 days after sowing were clearly different from those of the other treatments (Figs. 3A and 4A). In fact, the amount of PCR product in new rockwool samples on day 7 was below the detection limit of the applied procedure, giving only a few, unclear bands. This corroborated the finding of the 10-fold lower number of bacteria in new rockwool at day 7 compared with those of the three treatments with used rockwool (Fig. 2).

\section{DISCUSSION}

The experiments reported in this paper showed that the microflora in used rockwool plays an important role in suppressing root and crown rot symptoms, caused by $P$. aphanidermatum, in cucumber. After inoculating rockwool with $P$. aphanidermatum, significantly lower numbers of plants showing root and crown rot symptoms occurred in nonautoclaved than in autoclaved used rockwool. These results were obtained in five independent experiments with seven rockwool batches that were free of symptoms caused by Pythium in the preceding cucumber crop. On some batches of nonautoclaved rockwool, plants even showed the virtual absence of any symptom caused by Pythium after the addition of the pathogen. High levels of disease suppressiveness were also found in rockwool that had previously been used for other crops. New rockwool had, in one experiment, significantly more plants with root and crown rot than did used rockwool. Moreover, autoclaved used rockwool became suppressive after recolonization due to contact with saturated used rockwool. The most likely explanation for all these observations is that disease suppressiveness was caused by members of the microflora present in used rockwool.

TABLE 5. Mean number of bands in the bacterial PCR-DGGE patterns of different rockwool treatments on four sampling dates

\begin{tabular}{lrrrc}
\hline & \multicolumn{4}{c}{ Days after sowing } \\
\cline { 2 - 5 } Treatment & \multicolumn{1}{c}{7} & \multicolumn{1}{c}{14} & \multicolumn{1}{c}{21} & \multicolumn{1}{c}{35} \\
\hline Used rockwool & $9.0 \pm 4.0^{z}$ & $12.0 \pm 3.0$ & $11.3 \pm 0.6$ & $12.0 \pm 2.6$ \\
Autoclaved recolonized used rockwool & $11.3 \pm 3.5$ & $12.0 \pm 3.0$ & $12.0 \pm 1.0$ & $13.3 \pm 1.5$ \\
Autoclaved used rockwool & $6.3 \pm 2.1$ & $11.0 \pm 2.6$ & $11.3 \pm 1.5$ & $15.0 \pm 4.6$ \\
New rockwool & $1.3 \pm 1.5$ & $5.0 \pm 1.7$ & $10.3 \pm 2.1$ & $14.0 \pm 2.0$ \\
\hline
\end{tabular}

${ }^{\mathrm{z}}$ Mean number of bands \pm standard deviation, three replicates per treatment. 
The occurrence of suppressiveness to plant disease agents in soils has generally been accepted. Studies on the underlying mechanisms have resulted in the detection of important antagonists, e.g., nonpathogenic Fusarium oxysporum (1), Verticillium biguttatum (11), S. griseoviridis (31), P. nunn (12), and Pseudomonas spp. $(8,30)$. However, disease suppression in soilless systems, such as rockwool, is a hitherto undescribed phenomenon. Up to now, horticultural practice dictated that each crop should be grown as "sterile" as possible, i.e., using microbiologically 'clean' new or autoclaved substrates and disease-free plant material. As a result, $P$. aphanidermatum is likely to multiply explosively as soon as it infects the system. The presence or application of disease-suppressive microflora or effective antagonists will be a new method to minimize the risk of a Pythium outbreak. However, although used rockwool was found to be suppressive, it would be short-sighted to advise growers to use nonautoclaved rockwool, since Pythium infection in the preceding crop may cause large damages in the next crop. Also, the putative presence of other pathogens and pests such as insects and viruses does not always allow the use of nonautoclaved rockwool. Therefore, enhancement of the suppressiveness by introducing microorganisms or products stimulating the suppressive microflora will be a favored strategy. More knowledge about the mechanism and the microorganisms involved is obviously necessary to develop such methods of stimulation or enhancement of suppressiveness. Moreover, suppressive rockwool can be a source of effective antagonists with wider applicability.

In two separate experiments, disease suppressiveness could be transferred within 1.5 days by contact between water-saturated rockwool slabs. Therefore, the suppressive factor is probably easily transferable under wet conditions. However, it is unlikely that suppressiveness of rockwool is a general phenomenon caused by all members of the microbial community, since high numbers of bacteria did not correlate with disease suppression. Recolonization of autoclaved rockwool by bacteria occurred very fast. The cucumber nutrient solution added to the autoclaved used rockwool contained $10^{5} \mathrm{CFU} / \mathrm{ml}$, which, together with contaminations from the air or contact with greenhouse materials, allowed a population increase up to $10^{7}$ within 2 days. In all experiments with autoclaved used rockwool, the numbers of bacteria were, within 2 days, as high as or higher than those before autoclaving. This corresponds to the quick increase of bacterial numbers in the nutrient solution mentioned by Berkelmann (2). However, these populations were not suppressive.

Nonautoclaved, recolonized, and autoclaved used rockwool contained different dominant bacterial species as detected with PCRDGGE. Some bands, likely to represent dominant species, only occurred in the suppressive treatments. Although the total numbers of culturable bacteria were more or less similar in all treatments, the composition of the bacterial populations was often different. This might play a key role in suppressiveness. The PCR-DGGE pattern also changed during plant growth; more bands occurred at later time intervals and replicates were less similar. In soil, PCRDGGE analysis of bacterial communities associated with Chrysanthemum showed only a few changes in bacterial composition (5), probably due to the dominance of recalcitrant unculturable organisms in soil (7). The current study indicated that PCR-DGGE is a very powerful technique for the evaluation of the composition and diversity of the microflora in rockwool. By analyzing the bands that specifically occur in disease-suppressive treatments, it might be possible to detect bacterial species responsible for suppression of $P$. aphanidermatum.

The importance of fluorescent pseudomonads as effective antagonists is not yet clear. In spite of the fact that certain Pseudomonas isolates can control $P$. aphanidermatum in cucumber $(13,22,23)$, the total numbers of fluorescent pseudomonads did not correlate with the suppressiveness of used rockwool. Two other reasons favoring the idea that pseudomonads might be important nutrient competitors of Pythium are that they are fast-growing or- ganisms and that they can use many different readily available compounds. After sterilization of the used rockwool, such readily available compounds will leak out of the dead roots. However, high numbers of pseudomonads were present in autoclaved as well as in recolonized rockwool, and only the latter was suppressive. Nonautoclaved rockwool, which was also suppressive, contained low numbers of pseudomonads. The fact that total numbers of pseudomonads did not correlate with suppressiveness in used rockwool systems does not exclude the possibility that specific isolates or species might be responsible for the suppression of $P y$ thium. On the other hand, Pseudomonas isolates are good colonizers of living roots and can control Pythium infection by reducing the amount of exudates along the root surface (22), whereas the current study with autoclaved used rockwool deals with cucumber plants growing in a substrate with many dead roots. If Pseudomonas isolates are not able to colonize the interior parts of the dead roots sufficiently, Pythium will be able to colonize the roots and produce masses of spores, followed by infection of living plant roots.

Thus, to inhibit $P$. aphanidermatum infection by inhibiting its growth in dead roots, antagonists should be able to colonize the interior parts of dead root material. Fungi and actinomycetes are key organisms in decomposition processes of dead plant material. Actinomycetes have not been assessed in this study. Fungal populations, including Trichoderma spp., were present in both suppressive treatments, i.e., nonautoclaved and recolonized rockwool. They were present in low numbers in the highly diseased autoclaved rockwool at the start of the experiments and might cause (part of) the suppressiveness of used rockwool against $P$. aphanidermatum.

Disease suppressiveness of rockwool presents a hitherto little discussed phenomenon that can lead to the development of microbially balanced soilless cultivation systems. The fact that suppressiveness can be regained by transfer of the microflora in two test systems warrants further research on the underlying mechanism and microorganisms involved. In future work in our laboratories, actinomycetes and fungal populations will be studied in more detail.

\section{ACKNOWLEDGMENTS}

This study was supported, in part, by The Product Board for Horticulture in the Netherlands. We thank the Research Station for Floriculture and Glasshouse Vegetables and all growers who supplied rockwool slabs. We also thank ENZA Zaden BV and Rijk Zwaan for providing cucumber seeds; A. C. M. Clerkx, B. H. de Haas, J. B. L. Lankwarden, D. Zevenhuizen, and E. van der Hulst for technical assistance; and N. J. Fokkema for fruitful discussions.

\section{LITERATURE CITED}

1. Alabouvette, C., Rouxel, F., and Louvet, J. 1979. Characteristics of Fusarium wilt-suppressive soils and prospects for their utilization in biological control. Pages 165-182 in: Soil-Borne Plant Pathogens. B. Schippers and W. Gams, eds. Academic Press, New York.

2. Berkelmann, B. 1992. Characterisierung der Bakterienflora und des antagonistischen Potentials in der zirkulierinrenden Nährlösung einer Tomatenkultur (Lycopersicon esculentum MILL.) in Steinwolle. Ph.D. thesis. Forschungsanstalt Geisenheim, Germany. Geisenheimer Berichte Band 10.

3. Blancard, D., Lecoq, H., and Pitrat, M. 1994. A Color Atlas of Cucurbit Diseases: Observation, Identification and Control. Manson, London.

4. Bolton, A. T. 1980. Control of Pythium aphanidermatum in poinsettia in a soilless culture by Trichoderma viride and a Streptomyces sp. Can. J. Plant Pathol. 2:93-95.

5. Duineveld, B. M., Rosado, A. S., van Elsas, J. D., and van Veen, J. A. 1998. Analysis of the dynamics of bacterial communities in the rhizosphere of the chrysanthemum via denaturing gradient gel electrophoresis and substrate utilization patterns. Appl. Environ. Microbiol. 64:4950-4957.

6. Favrin, R. J., Rahe, J. E., and Mauza, B. 1988. Pythium spp. associated with crown rot of cucumbers in British Columbia greenhouses. Plant Dis. 72:683-687.

7. Gelsomino, A., Keijzer-Wolters, A. C., Cacco, G., and van Elsas, J. D. 1999. Assessment of bacterial community structure in soil by polymerase chain reaction and denaturing gradient gel electrophoresis. J. 
Microbiol. Methods 38:1-15.

8. Harrison, L. A., Letendre, L., Kovacevich, P., Pierson, E., and Weller, D. 1993. Purification of an antibiotic effective against Gaeumannomyces graminis var. tritici produced by a biocontrol agent, Pseudomonas aureofaciens. Soil Biol. Biochem. 25:215-221.

9. Hendrix, Jr., F. F., and Campbell, W. A. 1973. Pythiums as plant pathogens. Annu. Rev. Phytopathol. 11:77-98.

10. Heuer, H., and Smalla, K. 1997. Application of denaturing gradient gel electrophoresis and temperature gradient gel electrophoresis for studying soil microbial communities. Pages 353-373 in: Modern Soil Microbiology. J. D. van Elsas, J. T. Trevors, and E. M. H. Wellington, eds. Marcel Dekker, New York.

11. Jager, G., ten Hope, A., and Velvis, H. 1979. Hyperparasites of Rhizoctonia solani in Dutch potato fields. Neth. J. Plant Pathol. 14:86-91.

12. Lifshitz, R., Stanghellini, M. E., and Baker, R. 1984. A new species of Pythium isolated from soil in Colorado. Mycotaxon 20:373-379.

13. McCullagh, M., Utkede, R., Menzies, J. M., Punja, Z. K., and Paulitz, T. C. 1996. Evaluation of plant growth-promoting rhizobacteria for biological control of Pythium root rot of cucumbers grown in rockwool and effects on yield. Eur. J. Plant Pathol. 102:747-755.

14. Menzies, J. G., Ehret, D. L., and Stan, S. 1996. Effect of inoculum density of Pythium aphanidermatum on the growth and yield of cucumber plants grown in recirculating nutrient film culture. Can. J. Plant Pathol. 18:50-54.

15. Moulin, F., Lemanceau, P., and Alabouvette, C. 1994. Pathogenicity of Pythium species on cucumber in peat-sand, rockwool and hydroponics. Eur. J. Plant Pathol. 100:3-17.

16. Moulin, F., Lemanceau, P., and Alabouvette, C. 1994. Control by fluorescent pseudomonads of Pythium aphanidermatum root rot, responsible for yield reduction in soilless culture of cucumber. Pages 47-50 in: Improving Plant Productivity with Rhizosphere Bacteria. M. H. Ryder, P. H. Stephens, and G. D. Bowen, eds. CSIRO Australia, North Ryde, Australia.

17. Muyzer, G., De Waal, E. C., and Uitterlinden, A. G. 1993. Profiling of complex microbial populations by denaturing gradient gel electrophoresis analysis of polymerase chain reaction-amplified genes coding for $16 \mathrm{~S}$ rRNA. Appl. Environ. Microbiol. 59:695-700.

18. Muyzer, G., Hottenträger, S., Teske, A., and Wawer, C. 1996. Denaturing gradient gel electrophoresis of PCR-amplified $16 \mathrm{~S}$ rDNA-A new molecular approach to analyse the genetic diversity of mixed microbial communities. Pages 1-23 in: Molecular Microbial Ecology Manual 3.4.4. A. D. L. Akkermans, J. D. van Elsas, and F. J. de Bruijn, eds. Kluwer Academic Publishers, Dordrecht, the Netherlands.

19. Nelson, E. B., and Craft, C. M. 1992. A miniaturized and rapid bioassay for the selection of soil bacteria suppressive to Pythium blight of turfgrasses. Phytopathology 82:206-210.

20. Paternotte, S. J. 1992. Influence of growing conditions on disease devel- opment of Pythium in glasshouse cucumbers on rockwool. Meded. Fac. Landbouwwet. Rijksuniv. Gent 57:373-379.

21. Paulitz, T. C., Ahmad, J. S., and Baker, R. 1990. Integration of Pythium nunn and Trichoderma harzianum isolate T-95 for the biological control of Pythium damping-off of cucumber. Plant Soil 121:243-250.

22. Paulitz, T. C., Zhou, T., and Rankin, L. 1992. Selection of rhizosphere bacteria for biological control of Pythium aphanidermatum on hydroponically grown cucumber. Biol. Control 2:226-237.

23. Postma, J., Willemsen-de Klein, M. J. E. I. M., and Hoogland, A. E. 1996. Biocontrol of Pythium aphanidermatum in closed culture systems. IOBC/WPRS Bull. 19:42-46.

24. Rademaker, J. L. W., Louws, F. J., Rossbach, U., Vinuesa, P., and de Bruijn, F. J. 1999. Computer-assisted pattern analysis of molecular fingerprints and database construction. Pages 1-33 in: Molecular Microbial Ecology Manual 7.1.3. A. D. L. Akkermans, J. D. van Elsas, and F. J. de Bruijn, eds. Kluwer Academic Publishers, Dordrecht, the Netherlands.

25. Rankin, L., and Paulitz, T. C. 1994. Evaluation of rhizosphere bacteria for biological control of Pythium root rot of greenhouse cucumbers in hydroponic culture. Plant Dis. 78:447-451.

26. Rattink, H., and Postma, J. 1996. Biological control of Fusarium wilt in carnations on a recirculation system by a nonpathogenic Fusarium oxysporum isolate. Meded. Fac. Landbouwwet. Rijksuniv. Gent 61:491-498.

27. Sivan, A., Elad, Y., and Chet, I. 1984. Biological control effects of a new isolate of Trichoderma harzianum on Pythium aphanidermatum. Phytopathology 74:498-501.

28. Stanghellini, M. E., and Rasmussen, S. L. 1994. Hydroponics: A solution for zoosporic pathogens. Plant Dis. 78:1129-1138.

29. Stanghellini, M. E., Rasmussen, S. L., Kim, D. H., and Rorabaugh, P. A. 1996. Efficacy of nonionic surfactants in the control of zoospore spread of Pythium aphanidermatum in a recirculating hydroponic system. Plant Dis. 80:422-428.

30. Stutz, E. W., Défago, G., and Kern, H. 1986. Naturally occurring fluorescent pseudomonads involved in suppression of black root rot of tobacco. Phytopathology 76:181-185.

31. Tahvonen, R. 1982. The suppressiveness of Finnish light colored Sphagnum peat. J. Sci. Agric. Soc. Finl. 54:345-356.

32. Waechter-Kristensen, B., Gertsson, U. E., and Sundin, P. 1994. Prospects for microbial stabilization in the hydroponic culture of tomato using circulating nutrient solution. Acta Hortic. 361:382-387.

33. Whipps, J. M., and Lumsden, R. D. 1991. Biological control of Pythium species. Biocontrol Sci. Technol. 1:75-90.

34. Wolffhechel, H. 1988. The suppressiveness of sphagnum peat to Pythium spp. Acta Hortic. 221:217-222.

35. Wölk, M. 1990. Möglichkeiten des einsatzes von Bacterien gegenüber Rhizoctonia solani und Pythium aphanidermatum. Ph.D. thesis. University of Hohenheim, Stuttgart, Germany. 